\title{
Microtubule proteins and their post-translational forms in the cerebrospinal fluid of patients with paraparesis associated with HTLV-I infection and in SH-SY5Y cells: An in vitro model of HTLV-I-induced disease.
}

\author{
HORACIO MALDONADO ${ }^{1}$, EMILIO ORTIZ-RIAÑO ${ }^{1}$, BERNARDO KRAUSE ${ }^{1}$, \\ ANDRÉS BARRIGA ${ }^{1}$, FERNANDO MEDINA ${ }^{1}$, M ELSA PANDO $^{1}$, CAROLINA $^{2}$ \\ ALBERTI ${ }^{1}$, ANA M KETTLUN ${ }^{1}$, LUCÍA COLLADOS $^{1}$, LORENA GARCÍA $^{1}$, \\ LUIS CARTIER $^{2}$, and M ANTONIETA VALENZUELA ${ }^{1}$.
}

\footnotetext{
${ }^{1}$ Departamento de Bioquímica y Biología Molecular, Facultad de Ciencias Química y Farmacéuticas, Universidad de Chile, Santiago, Chile.

${ }^{2}$ Departamento de Ciencias Neurológicas, Facultad de Medicina, Universidad de Chile, Santiago, Chile.
}

\begin{abstract}
HTLV-I-associated myelopathy/tropical spastic paraparesis (HAM/TSP) is characterized by axonal degeneration of the corticospinal tracts. The specific requirements for transport of proteins and organelles to the distal part of the long axon are crucial in the corticospinal tracts. Microtubule dysfunction could be involved in this disease, configuring an axonal transport disease. We measured tubulin and its posttranslational modified forms (acetylated and tyrosinated) in CSF of patients and controls, as well as tau and its phosphorylated forms. There were no significant differences in the contents of tubulin and acetyl-tubulin between patients and controls; tyrosyl-tubulin was not detected. In HAM/TSP, tau levels were significantly reduced, while the ratio of $\mathrm{pT}^{181} /$ total tau was higher in patients than in controls, this being completely different from what is reported in other neurodegenerative diseases. Phosphorylation at $\mathrm{T}^{181}$ was also confirmed by Mass Spectrometry analysis. Western Blotting with monospecific polyclonal antibodies against $\mathrm{pS}^{199}, \mathrm{pT}^{205}, \mathrm{pT}^{231}, \mathrm{pS}^{262}, \mathrm{pS}^{356}, \mathrm{pS}^{396}, \mathrm{pS}^{404}$ and $\mathrm{pS}^{422}$ did not show differences in phosphorylation in these residues between patients and controls. Treating human SH-SY5Y neuroblastoma cells, a well-known in vitro neurite retraction model, with culture supernatant of MT-2 cells (HTLV-I infected cell line that secretes the viral Tax protein) we observed neurite retraction and an increase in tau phosphorylation at $\mathrm{T}^{181}$. A disruption of normal phosphorylation of tau protein in $\mathrm{T}^{181}$ could result in its dysfunction, contributing to axonal damage.
\end{abstract}

Key terms: Tropical spastic paraparesis, cerebrospinal fluid, SH-SY5Y cells, retraction, tau, phosphorylatedtau forms, tubulin, acetyl-tubulin

\section{INTRODUCTION}

HTLV-I-associated myelopathy/tropical spastic paraparesis (HAM/TSP) is characterized by the bilateral loss of axons in the corticospinal tracts (Cartier et al., 1997). This central axonopathy could originate from axoplamic transport impairment as suggested from immunohistological observations of amyloid precursor protein (APP) accumulation, usually associated with alteration in anterograde axonal transport (Umehara et al., 2000; Cartier et al., 2007). $\mathrm{HAM} / \mathrm{TSP}$ shows clinical and histopathological similarities with hereditary spastic paraplegia, where axonal degeneration seems to arise from impairment of axonal transport (Ferreirinha et al., 2004; De Luca et al., 2004). 
CD4+ cells are the main reservoir of HTLV-I; both CD8+ cells and astrocytes may also be infected, but not neurons (Grant et al., 2002). Since axonal degeneration occurs without infection of neurons, HTLV-I should exert its effects through extracellular action of the secreted viral protein Tax, chronically present in CSF of HAM/TSP patients (Szymocha et al., 2000; Osame, 2002; Cartier \& Ramírez, 2005; Jain et al., 2007). Neither inflammatory nor immune hypotheses explain the pathogeny of HAM/TSP in $40 \%$ of clinically identical patients who are seronegative, but have the tax gene (Ramírez et al., 2003). Studies in vitro have shown Tax binding to many cellular proteins, which regulate transcription and cytoskeleton-related pathways ( $\mathrm{Wu}$ et al., 2004). The phosphatase PP2, involved in the balance of phosphorylation of cytoskeletal proteins, is inhibited by formation of a ternary complex Tax-Ikk $\gamma$ PP2A (Fu et al., 2003).

$\alpha$ - and $\beta$-tubulins, the primary components of microtubules, undergo several post- translational modifications, including acetylation and detyrosination (Kreitzer et al., 1999; Nogales, 2000). While acetyl-tubulin is associated with stable structures, tyrosyl-tubulin is characteristic of dynamic structures. Another protein involved in microtubular dynamics and transport is tau, functionally modulated by phosphorylation (Buée et al., 2000; Avila et al., 2004). Tau is involved in microtubule dynamics promoting tubulin polymerization, stabilization of microtubules, controlling attachment/ detachment of motor proteins, and participation in signal transduction and organelle transport (Trinczek et al., 1999; Buée et al., 2000; Avila et al., 2004, Mondragón-Rodríguez et al., 2008). Tau functions are modulated by site-specific phosphorylations, these being deregulations of kinases and phosphatases associated with abnormal hyperphosphorylation of tau in several neurodegenerative diseases (Avila et al., 2004; Johnson \& Stoothoff, 2004; Iqbal et al., 2005; Sergeant et al., 2005; Wang et al., 2007). Both normal and structurally altered cytosolic proteins are released from the CNS into CSF, so that CSF proteins reflect changes in the CNS (Alonso et al., 2006; Maccioni et al., 2006; Blennow et al., 2007).

In the present study we have measured the relative amounts of microtubule proteins, including their post-translationally modified forms in CSF of HAM/TSP and compared to those of control subjects. While no differences in tubulin and acetyl-tubulin were found between these two groups of study, in HAM/TSP tau levels were significantly reduced with higher phosphorylation at threonine-181 ( $\left.\mathrm{pT}^{181}\right)$, thus the ratio of $\mathrm{pT}^{181} /$ total tau was higher than that in controls and other neurodegenerative disorders. Neurite retraction in response to extracellular signals occurs in neurodegeneration, therefore the use of neuronal cell culture as an in vitro model of neurite retraction could be a useful tool for understanding molecular mechanisms of neurodegeneration (Sayas et al., 2002). In HAM/TSP, the injury has been attributed to viral proteins secreted from infected CD4+ cells present in the CNS (Osame, 2002; Grant et al., 2002; Cartier \& Ramírez, 2005). The treatment of human SH-SY5Y neuroblastoma cells (Sayas et al., 2002; Jämsä et al., 2004) with culture supernatant of MT-2 cells, a HTLV-I infected cell line that secretes the viral Tax protein (Alephantis et al., 2005), produces neurite retraction and an increase in tau phosphorylation at $\mathrm{T}^{181}$.

\section{MATERIALS AND METHODS}

\section{CSF samples}

CSF was obtained from 14 patients with HAM/TSP (aged 45-68), with a diseaseduration of 2-8 years. These were identified both clinically and by determination of specific antibodies reacting with viral antigens in serum (Galeno et al., 1994). The control group (all seronegative) was composed of 16 subjects (aged 48-69), including people without neurological disorders from gynecology (spinal anesthesia) and with non-inflammatory or non-degenerative neurological diseases that 
required lumbar puncture (cephalgia, neuropathy). Controls and patient groups were duly informed of the research protocol approved by the Clinical Research Ethics Committee of the Hospital del Salvador, Santiago, Chile. CSF samples were obtained by lumbar puncture as part of the normal procedures and were frozen at $-20^{\circ} \mathrm{C}$. CSF from HAM/TSP had a cell count of $0-12$ per $\mu l$, and an average concentration of human serum albumin (HSA) of $0.16 \pm 0.09 \mathrm{mg} / \mathrm{ml}$; CSF from the control group had a cell count of $0-5$ cells per $\mu l$, and average of HSA of $0.21 \pm 0.07$. In the HAM/TSP group there were no correlations between cell counts, years of disease and functional level (bedridden, wheelchair, gait with support, gait with and without support).

Human SH-SY5Y cell cultures and neurite retraction studies

Human SH-SY5Y neuroblastoma was maintained in a mixture of Dulbecco's modified Eagle's nutrient medium and F12 -Ham in a 1:1 proportion (Sigma-Aldrich, St Louis, MO USA) supplemented with 6\% heat-inactivated fetal calf serum (FBS) (Hyclone, Thermo Fischer Scientific Inc, South Logan, UT, USA). Cells were seeded at an initial density of $2.2 \times 10^{3}$ cells $/ \mathrm{cm}^{2}$. The differentiation protocol was based on the report of Jämsä et al. (2004), with some modifications. Briefly, after 24 hours of seeding the differentiation, a neuronal-type was induced by the addition of $10 \mu \mathrm{M}$ alltrans-retinoic acid (Sigma), with gradual daily reductions of the FBS concentration (from 6 to $0 \%$ ) over 5 days. Then $50 \mathrm{ng} / \mathrm{ml}$ BDNF (Alomone Laboratories, Jerusalem, Israel) was added for 2 days. BDNF was removed and the culture medium of $\mathrm{SH}$ SY5Y cells was replaced by a DMEM-F12 Ham mixture without serum, four hours prior to the addition of the supernatants of MT-2 and K562 cultures. MT-2 and K562 cells (5 to 10 million in $10 \mathrm{ml}$ ) were cultivated in RPMI, as reported by Ramírez et al. (2004) except for reduction in FBS from 10 to $0.2 \%$ for 7 to 14 days.

Cell extracts were prepared as follows: cells were washed with phosphate buffered saline and then re-suspended in a RIPA buffer (25 mM Tris-HCl pH 7.6, $150 \mathrm{mM}$ $\mathrm{NaCl}, 1 \%$ Nonidet $\mathrm{P} 40,1 \%$ sodium deoxycholate, $0.1 \%$ SDS), protease inhibitor cocktail $2 \mu \mathrm{l} / \mathrm{mL}$ (Cat P8340, Sigma-Aldrich) and $1 \mathrm{mM}$ sodium-ovanadate following mechanical disruption. The soluble fraction was obtained by centrifugation at $14,000 \times \mathrm{g}$ for $15 \mathrm{~min}$ at $4^{\circ} \mathrm{C}$. Protein determination was done using the BCA Protein Assay kit from Pierce (Pierce, IL, USA), according to the manufacturer's instructions.

\section{Neurite length measurement}

Cultures were examined under a phase microscope and captured directly as digital micrographs in black and white. Images were acquired using a $20 x$ objective lens and photographs taken from 7 different fields, with $\mathrm{Z}$ configuration, were analyzed. Neurite length was measured using the NIH ImageJ-1.38d plug-in program neuronJ. Neurite length corresponds to the net extension away from the cell body, i.e. from the margin of the cell body to its terminus. The measurement was made using the program's handheld cursor. Data collected from 200-300 neurites were used for each condition, and the program gives the population's average neurite length in pixel counts on digitized images. All neurites measured were included in the statistical tests.

\section{Human albumin concentration of CSF}

Human albumin analysis by capillary zone electrophoresis was performed on an Ion Analyzer Capillary Electrophoresis System (Waters, Mildford, MA, USA) with Millennium software (Waters) for data handling. The separation was performed at $18 \mathrm{kV}$ using an uncoated fused-silica capillary of $60 \mathrm{~cm}$ x $50 \mu \mathrm{m}$, with $150 \mathrm{mM}$ phosphoric acid as an electrolyte, at $25^{\circ}$. The sample was introduced by hydrodynamic injection (10 cm height) for $30 \mathrm{~s}$, the detection was made at $185 \mathrm{~nm}$. The human serum albumin (HSA) peak was assigned by adding a standard solution of HSA. 


\section{Western Blotting analysis}

Adequate antibody dilutions were tested by dot blot. SDS/PAGE was performed with $10 \%$ polyacrylamide gels (for tubulin studies) or $12 \%$ (for tau analysis). Portions of $10 \mu \mathrm{l}$ of CSF and $20 \mu \mathrm{g}$ protein of cell lysate were used. The buffer for electrotransfer to nitrocellulose membranes (BioRad, Hercules, CA, USA) contained $25 \mathrm{mM}$ Tris-HCl, $192 \mathrm{mM}$ glycine and $20 \%(\mathrm{v} / \mathrm{v})$ methanol, and electrotransfer was done at a total of 600 $\mathrm{mA}$ at $4{ }^{\circ} \mathrm{C}$. After electrotransfer, membranes were blocked for $1 \mathrm{~h}$ at room temperature with 6\% Quick-Blocker dissolved in TBS-T (20 mM Tris- $\mathrm{HCl}, 137$ $\mathrm{mM} \mathrm{NaCl}, 0.1 \%(\mathrm{v} / \mathrm{v})$ Tween-20, $\mathrm{pH} 7.6$ ), then incubated overnight at $4{ }^{\circ} \mathrm{C}$ with the different primary antibodies at the appropriate dilution in TBS-T buffer. The following monoclonal antibodies were used: against acetyl-tubulin (dilution 1:50; Cat T6793, Sigma-Aldrich, Inc, St Louis, MO, USA); against tyrosyl-tubulin (dilution 1:50; Cat T9028, Sigma-Aldrich); and against HSA (dilution 1:2000; Cat. MON5024, Monosan, Brussels, Belgium). The following polyclonal antibodies were used: against tubulin (1:200; Cat. T3526, Sigma-Aldrich); against total tau (dilution 1:1,000, Cat AH0042, TAU-5, BioSourceInvitrogen Corporation, Carlsbad, CA, USA). The following polyclonal antibodies were used: against tubulin (1:200; Cat. T3526, Sigma-Aldrich); against tau (dilution 1:1,000; Cat T1032, US Biological, Swampscott, MA, USA); against tau-phospho T181 (1:1,000; Cat. ab38505, Abcam, Cambridge, UK), and against nine different phosphorylated residues of tau (dilution 1:5000, BioSource-Invitrogen Corporation). After washing three times (10 min each wash) with TBS-T (without milk), membranes were incubated with the corresponding secondary antibody. As a secondary antibody we used: anti-rabbit conjugated with peroxidase diluted 1: 20,000 (Cat. 1858415, Pierce, IL, USA) or anti-mouse conjugated with peroxidase diluted 1:10,000 (Cat. 1858413, Pierce). Blots were incubated for $1 \mathrm{~h}$ with peroxidase- conjugated secondary antibodies. After rinsing three times (10 $\mathrm{min}$ each rinse) with TBS-T (without milk), positive reactions were identified using enhanced chemiluminiscence SuperSignal West Pico Chemiluminiscent substrate (Pierce) in the case of analysis of tubulin and their modified forms, and using SuperSignal West Femto Chemiluminiscent substrate (Pierce) in all the other analyses. X-ray films (CL-Xposure film, Pierce) were exposed for varying times. Control experiments (without primary antibodies) with only secondary antibodies did not give any chemiluminescent signal. For consecutive analyses with various antibodies, stripping was performed using the ReBlot plus mild antibody solution (Chemicon) according to the manufacturer's instructions. Blots were then blocked and probing was performed as above.

\section{Immunodot blot analysis}

Analysis of tubulin and acetyl-tubulin in CSF by Western Blotting showed the presence of a single protein band with the corresponding molecular weight (close to $100 \mathrm{kDa}$ ); there was no signal with antityrosyl-tubulin. The relative amounts of tubulin and acetyl-tubulin were determined by dot blot, by applying portions (10 $\mu$ l for acetyl-tubulin, $5 \mu$ f for tubulin) to the nitrocellulose membrane. CSF samples from HAM/TSP and controls were tested on the same membrane. Dilutions of primary and secondary antibodies were the same as used for the Western Blotting.

Determination of tau and tau phosphorylation at Thr181 ( $\left.T^{181}\right)$

Total tau and tau phosphorylated at $\mathrm{T}^{181}$ were determined using ELISA kits (Cats. KHB-0042 and KHO-0631, Biosource International), both designed for CSF analysis. The kit for total tau uses as standard recombinant human tau-441 expressed in E. coli, and the kit for human tau $\left[\mathrm{T}^{181}\right]$ used the same recombinant human tau-441 phosphorylated in vitro with GSK-3 $\beta$. 
Densitometric analysis of dot blotting and Western Blotting

Western Blot or dot blot signals from CSF samples were scanned and quantified using the "Un-scan-it gel" Graph Gel Digitizing software (Silk Scientific Corporation, Orem, UT, USA). Values of integrated density are reported in Arbitrary Units (pixels).

\section{Human serum albumin removal (HSA)}

Albumin was removed from CSF samples using the Montage Albumin Deplete Kit (Millipore, Billerica, MA, USA). Albumin removal from a sample was optimized processing through the affinity column at least eight times, instead of the two times recommended by the manufacturer. Albumin removal was followed by both capillary electrophoresis and western blot using monoclonal antibodies.

\section{Immobilized gallium(III) affinity chromatography}

To enrich for phosphopeptides, a commercially available phosphopeptide isolation kit (SwellGel ${ }^{\circledR}$ Gallium-Chelated Disc from Pierce) was used, following the manufacturer instructions.

\section{Protein digestion and Mass Spectrometry analysis}

A portion of $2 \mathrm{ml}$ of CSF of a patient was concentrated by centrifugation with Centricon ${ }^{\circledR}$ column YM-30 (Millipore corporation, Billerica, MA, USA), then the albumin was removed as described above with further concentration by speed vac. The pellet was resuspended in $100 \mu \mathrm{l}$ of 50 $\mathrm{mM} \mathrm{NH_{4 }} \mathrm{HCO}_{3}$. The solubilized proteins were reduced by adding $25 \mu \mathrm{l}$ of $45 \mathrm{mM}$ DTT $\left(45^{\circ} \mathrm{C}, 15\right.$ minutes) and then alkylated with $25 \mu \mathrm{l}$ of $100 \mathrm{mM}$ iodoacetamide at room temperature for 20 minutes. Trypsin digestion was carried out adding $2 \mu \mathrm{g}$ of porcine trypsin (Promega, Madison, WI, USA) at $37{ }^{\circ} \mathrm{C}$ for 24 hours. Reaction was concluded by freezing the sample at $-20{ }^{\circ} \mathrm{C}$ and it was kept frozen until the analysis.
Tryptic peptides were concentrated to dryness using speed vac centrifuge and dissolved in $0.1 \% \mathrm{v} / \mathrm{v}$ formic acid. An aliquot of each sample was desalted using Zip Tip C18 (Millipore, Billerica, MA, USA). A stock solution of $\alpha$-cyano-4hydroxycinnamic acid (CHCA) matrix was prepared by dissolving $10 \mathrm{mg} / \mathrm{ml}$ solution in $50 \% \mathrm{v} / \mathrm{v}$ acetonitrile and $0.05 \% \mathrm{v} / \mathrm{v}$ formic acid, and a stock solution of 2,4dihydroxybenzoic acid (DHB) matrix by dissolving $20 \mathrm{mg} / \mathrm{ml}$ solution in $50 \% \mathrm{v} / \mathrm{v}$ acetonitrile and $1 \% \mathrm{v} / \mathrm{v}$ phosphoric acid. Portions of $1 \mu \mathrm{l}$ of a mixture 1:1 or 1:10 of the sample and matrix solution were spotted on a micro scout target. Additionally $1 \mu \mathrm{l}$ of $25 \mathrm{mM}$ ammonium citrate was added to CHCA preparations. Mass spectra were acquired in a Microflex MALDI-TOF instrument (Bruker Daltonics, Inc. MAUSA) in positive and reflection mode. Before mass spectra acquisition, the instrument was externally calibrated using a peptide mix of a 1,000-3,000 mass range. Final spectra corresponded to 15 scans of 30 laser shots rastered uniformly across the sample spot.

Mass spectra data were examined for identification of putative phosphorylation sites using the PeptideMap tool (PROWL The Rockefeller University, http:// prowl.rockefeller.edu). All the searches were performed considering cysteine modified with iodoacetamide as fixedmodification, oxidized methionine and phosphorylation on serine and threonine as partial modifications, three incomplete proteolytic cleavages, a peptide mass tolerance between 0.1-0.3 Da and the human tau sequence (gi:6754638).

\section{Statistical analysis}

All statistical analyses in these studies were performed with the Statistical Package of the Social Sciences (SPSS). Differences between means of HAM/TSP patients and controls were evaluated using the Student's t-test for two independentsamples. When data did not conform to a normal distribution according to the Shapiro-Wilks test, they were normalized using the $\log _{10}$ transformation. The 
statistical analysis of neurite outgrowth between both studied groups at the same evaluation time was carried out using the Student's t-test for two independentsamples. Statistical significance was assumed at $\mathrm{p}<0.05$.

\section{RESULTS}

Tubulin and acetyl-tubulin in CSF of HAM/ TSP

Comparison of the levels of tubulin and acetyl-tubulin (relative to albumin concentrations) in CSF samples from HAM/ TSP and controls did not show significant differences. Tyrosyl-tubulin was not detected.

Determination of tau and tau phosphorylation at $T^{181}$

CSF concentrations of total tau and phosphorylated tau at $\mathrm{T}^{181}$ in patients and control subjects were determined by ELISA. There was a significant decrease in the concentration of total tau and a high concentration of the $\mathrm{pT}^{181}$ epitope in CSF samples from HAM/TSP with significantly higher $\mathrm{pT}^{181} /$ total tau ratio compared to controls (Table I). No correlation between CSF tau phosphorylation at $\mathrm{T}^{181}$ with the years of the disease was found.

\section{Other phosphorylated forms of tau in CSF}

A main band of $52 \mathrm{kDa}$ and a much less intense band of $63 \mathrm{kDa}$ were detected when the membrane was developed with anti-tau (Figure 1, lane B). The various monospecific polyclonal antibodies against diverse phosphorylation sites mainly showed the $52 \mathrm{kDa}$ band. As a representative case, reactivity to the antibody against $\mathrm{T}^{205}$ is shown in Figure 1 (lane C). Immunoreactive bands against both unphosphorylated and phosphorylated forms of tau with $\mathrm{Mw}$ between $52-55 \mathrm{kDa}$ have already reported (Sjogren et al., 2001, Borroni et al., 2007).

Abnormal hyperphosphorylation of various residues including $\mathrm{S}^{199}, \mathrm{~T}^{205}, \mathrm{~T}^{231}$, $\mathrm{S}^{262}, \mathrm{~S}^{356}, \mathrm{~S}^{396}, \mathrm{~S}^{404}$ and $\mathrm{S}^{422}$, was evaluated by Western blotting, using a battery of mono-specific polyclonal antibodies with CSF samples of both patients and controls on the same nitrocellulose membrane. Densitometric analyses of the phosphorylated residue bands and the same band revealed that antibodies that recognized total tau were expressed as Arbitrary Units (pixels). The results expressed as the ratio of P-residue $/ 52 \mathrm{kDa}$ tau isoform are shown in Table II. Data expressed as the ratio of P-residue $/ 52 \mathrm{kDa}$ tau isoform or P-residue/mg HSA (data not shown) were not different in patients compared to those of controls.

CSF levels of phospho-tau $\left(\mathrm{pT}^{181}\right)$ and total tau by ELISA test

\begin{tabular}{|c|c|c|c|c|c|}
\hline & & $\begin{array}{l}\text { Number } \\
\text { of subjects }\end{array}$ & $\begin{array}{c}\text { Range } \\
\text { (pg/mL CSF) }\end{array}$ & $\begin{array}{l}\text { Mean value } \pm \text { SD } \\
\text { (pg/mL CSF) }\end{array}$ & $\mathrm{p}$ value $^{\mathrm{a}}$ \\
\hline $\mathrm{pT}^{181}$ & $\begin{array}{l}\text { Controls } \\
\text { HAM/TSP }\end{array}$ & $\begin{array}{l}16 \\
14\end{array}$ & $\begin{array}{c}2.6-28.4 \\
4.3-141.1\end{array}$ & $\begin{array}{c}12.5 \pm 7.41 \\
35.8 \pm 34.03\end{array}$ & 0.010 \\
\hline Total tau & $\begin{array}{l}\text { Controls } \\
\text { HAM/TSP }\end{array}$ & $\begin{array}{l}16 \\
14\end{array}$ & $\begin{array}{c}30.9-253.5 \\
7.7-157.6\end{array}$ & $\begin{array}{c}108.8 \pm 59.31 \\
64.6 \pm 54.85\end{array}$ & 0.016 \\
\hline $\mathrm{pT}^{181} /$ total tau & $\begin{array}{l}\text { Controls } \\
\text { HAM/TSP }\end{array}$ & $\begin{array}{l}16 \\
14\end{array}$ & $\begin{array}{c}0.04-0.41 \\
0.13-14.86\end{array}$ & $\begin{array}{l}0.13 \pm 0.09 \\
1.68 \pm 3.77\end{array}$ & 0.000 \\
\hline
\end{tabular}

a Data were normalized using a $\log _{10}$ transformation, thus allowing the analysis by Student's t-test. 
Mass Spectrometry analysis of phosphorylated peptides of tau

The presence in CSF of phosphorylation of tau in $T^{181}$ was also confirmed employing the MALDI-TOF technique. To improve the sensibility of the analysis, we previously removed the large excess of human albumin that is also phosphorylated. Fig 2 shows the electropherogram of a CSF sample before and after the removal of albumin. Significant albumin removal was also observed by western blot analysis (data not shown). MALDI-TOF mass spectra of the phosphorylated peptides isolated from the gallium (III) affinity chromatography is shown in Fig 3. The peptide analysis indicated the presence of a phosphorylated peptide with the $\mathrm{m} / \mathrm{z}$ of 1076.525 , corresponding to the sequence $\mathrm{T}^{181} \mathrm{PPSSGEPPK}$, and confirming the presence of phosphorylation in $T^{181}$. Phosphorylation of the two serine residues is not reported. The low proportion of tau in CSF prevented us from analysing all the CSF samples because a large volume of CSF is required.

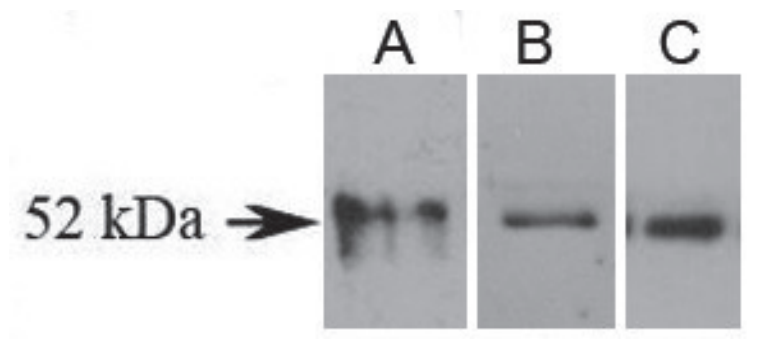

Figure 1: Tau and a phosphorylated form in CSF, followed by Western Blotting. Lanes A and B: show immunoreactivity against polyclonal antibodies (US Biological) against tau (dilution 1:1,000), A: a SH-SY5Y cell lysate used as positive control, and B: a CSF sample. Lane C: CSF sample developed with polyclonal antibodies (Invitrogen-BioSource) against $\mathrm{pT}^{205}$ (dilution 1:5,000).

\section{TABLE II}

CSF levels of tau phosphorylated residues followed by Western Blotting. Controls $\mathrm{n}=14$; Patients $\mathrm{n}=12$.

\begin{tabular}{|c|c|c|c|c|}
\hline Residue number & & $\begin{array}{c}\text { Range } \\
\text { P-residue } / 52 \mathrm{kDa} \text { tau } \\
\text { isoform }\end{array}$ & $\begin{array}{l}\text { Mean value } \pm \mathrm{SD} \\
\text { P-residue } / 52 \mathrm{kDa} \text { tau } \\
\text { isoform }\end{array}$ & $\mathrm{p}$ value \\
\hline $\mathrm{pS}^{199}$ & $\begin{array}{l}\text { Controls } \\
\text { HAM/TSP }\end{array}$ & $\begin{array}{l}0.07-3.45 \\
0.04-5.33\end{array}$ & $\begin{array}{l}2.00 \pm 1.06 \\
2.16 \pm 1.64\end{array}$ & 0.772 \\
\hline $\mathrm{pT}^{205}$ & $\begin{array}{l}\text { Controls } \\
\text { HAM/TSP }\end{array}$ & $\begin{array}{c}2.04-27.23 \\
1.11-8.75\end{array}$ & $\begin{array}{l}6.38 \pm 6.56 \\
3.99 \pm 2.02\end{array}$ & $0.213^{\mathrm{a}}$ \\
\hline $\mathrm{pS}^{262}$ & $\begin{array}{l}\text { Controls } \\
\text { HAM/TSP }\end{array}$ & $\begin{array}{l}0.59-6.93 \\
1.01-8.52\end{array}$ & $\begin{array}{l}3.63 \pm 2.19 \\
3.65 \pm 2.31\end{array}$ & 0.987 \\
\hline $\mathrm{pS}^{356}$ & $\begin{array}{l}\text { Controls } \\
\text { HAM/TSP }\end{array}$ & $\begin{array}{c}0.52-23.36 \\
0.91-5.90\end{array}$ & $\begin{array}{l}5.22 \pm 5.98 \\
3.19 \pm 1.67\end{array}$ & $0.540^{\mathrm{a}}$ \\
\hline $\mathrm{pS}^{396}$ & $\begin{array}{l}\text { Controls } \\
\text { HAM/TSP }\end{array}$ & $\begin{array}{l}2.72-15.16 \\
0.04-16.97\end{array}$ & $\begin{array}{l}6.69 \pm 3.58 \\
5.89 \pm 4.92\end{array}$ & 0.650 \\
\hline $\mathrm{pS}^{404}$ & $\begin{array}{l}\text { Controls } \\
\text { HAM/TSP }\end{array}$ & $\begin{array}{l}0.99-3.84 \\
0.18-3.80\end{array}$ & $\begin{array}{l}2.39 \pm 0.89 \\
2.19 \pm 1.61\end{array}$ & 0.780 \\
\hline $\mathrm{pS}^{422}$ & $\begin{array}{l}\text { Controls } \\
\text { HAM/TSP }\end{array}$ & $\begin{array}{l}0.80-12.15 \\
0.59-13.05\end{array}$ & $\begin{array}{l}4.18 \pm 3.64 \\
4.69 \pm 4.26\end{array}$ & 0.800 \\
\hline
\end{tabular}

aData were normalized using a $\log _{10}$ transformation, thus allowing the analysis by Student's t-test. The other data show a normal distribution. 


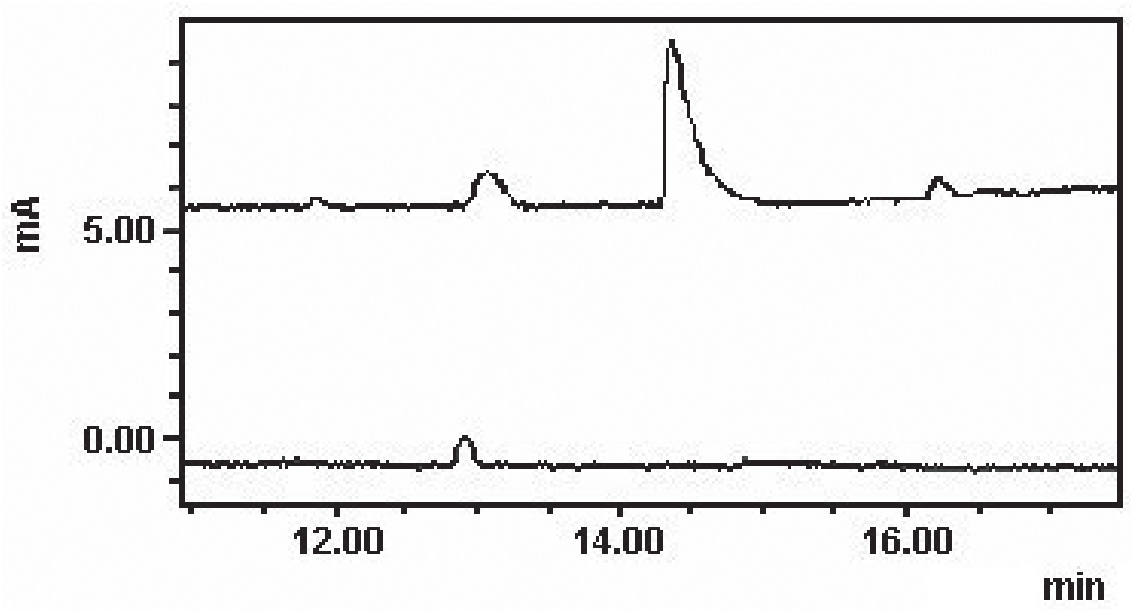

Figure 2: Human Albumin removal from CSF, followed by Capillary Electrophoresis. Upper line represents the electropherogram of the CSF without treatment where the main peak corresponds to HSA and the lower line is the electropherogram after treatment. As electrolyte, a solution of 150 $\mathrm{mM}$ phosphoric acid was used, electrophoretic conditions at $18 \mathrm{kV}$, with detection at $185 \mathrm{~nm}$.

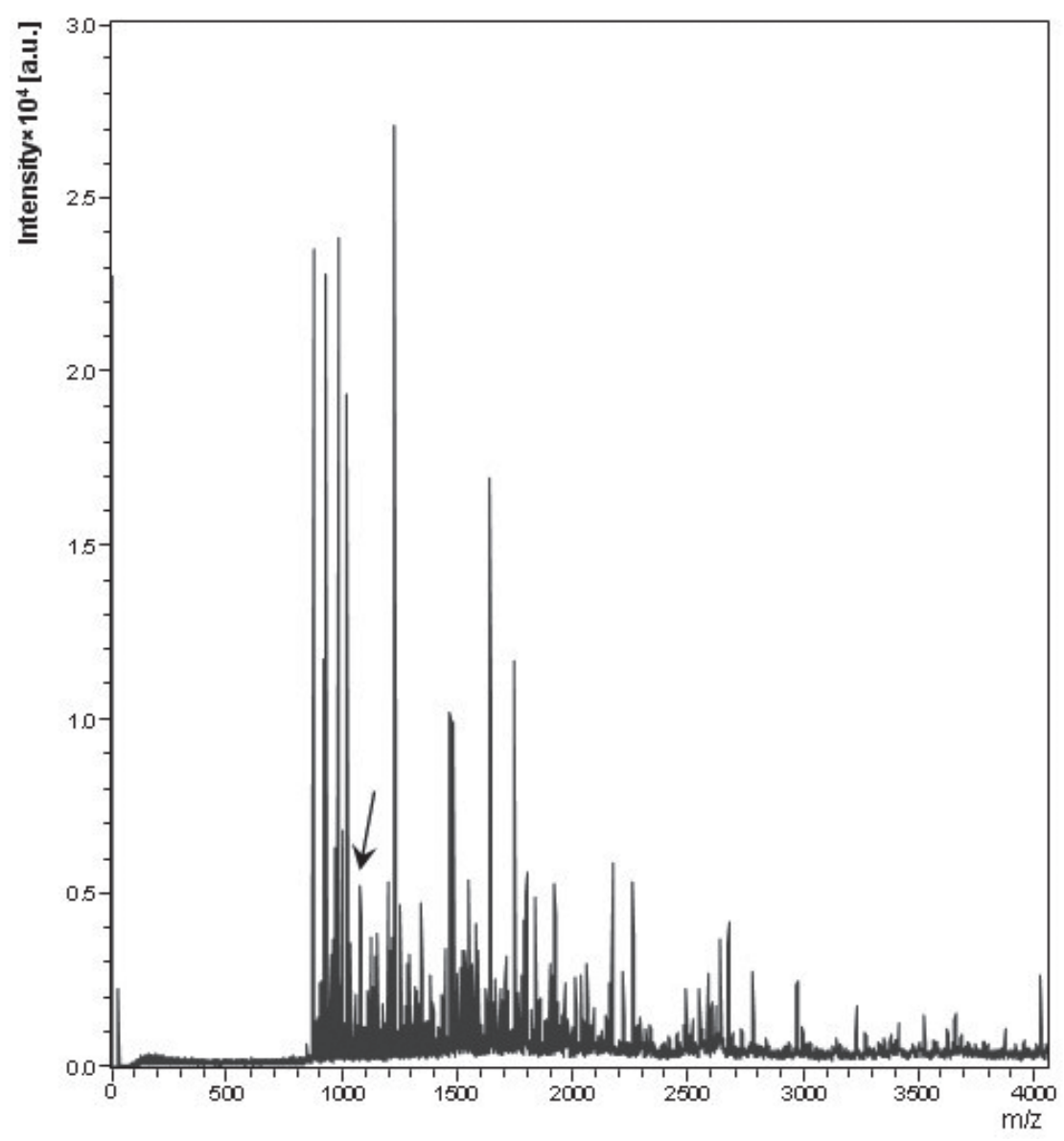

Figure 3: MALDI-TOF spectrum of phosphopeptides isolated from CSF. Tau phosphopeptide $\mathrm{T}^{181}$ PPSSGEPPK was identified among the phosphopeptides present in a tryptic digested CSF sample further purified using an immobilized $\mathrm{Ga}(\mathrm{III})$ column by database search. The arrow indicates the peak at $\mathrm{m} / \mathrm{z}, 1076.525$ representing the phosphorylated peptide. 
Neurite retraction and phosphorylation of tau at $T^{181}$ in cell culture model

With the purpose of initiating further studies in a cell line model, a culture of differentiated human SH-SY5Y neuroblastoma cells was treated for $60 \mathrm{~min}$ with culture supernatant of MT-2 cells (HTLV-I infected) (Fig 4). The treatment produced a significant reduction in the neurite length while the control experiment of SH-SY5Y cells incubated with supernatant of K562 cells maintained the initial neurite length (Fig 4 and 5A). Western blot analysis of cell lysates, shown in Fig 5B, indicated a hyperphosphorylation of tau at $\mathrm{T}^{181}$ in neuroblatoma cells treated with the supernatant of MT-2 cells that contains secreted viral proteins (Alefantis et al., 2005). The major immunoreactive band against pT181 and total tau (data not shown) showed the similar $\mathrm{Mw}$ of $52 \mathrm{kDa}$, as that observed in CSF (Fig. 1). No changes in total tau protein were observed. According to the literature in differentiated cell culture, a band with $\mathrm{Mw}$ of 48 is immunoreactive, with the same specific antibodies against different phosphoforms of tau as used in our study (Jämsä et al., 2004).

\section{DISCUSSION}

In CSF of HAM/TSP neither tubulin nor acetyl-tubulin showed significant changes compared to the control group. Tyr-tubulin was not detected in CSF. Our results contrast with those reported in MS, another chronic neurological disease with axonal degeneration (axonopathy), loss of myelin and APP axonal accumulation, where tubulin concentration in CSF correlated with disease progression, increasing in patients with progressive MS (Semra et al., 2002, Teunissen et al., 2005). We have not found any reports on measurements of these post-translational modifications of tubulin in CSF.

It has been suggested that increased intrathecal release of tau reflects the degree of neuronal degeneration and damage (Bartosik-Psujek \& Stelmasiak, 2006; Otto et al., 2008). Total tau has been found to be increased in Alzheimer' disease (AD), semantic dementia (SD), multiple sclerosis (MS), amyotropic lateral sclerosis (ALS), Creutzfeldt-Jakob disease (CJD), and Guillain-Barré syndrome (Brettschneider et al., 2006a,b; Bartosik-Psujek \& Stelmasiak, 2006; Buerguer et al., 2006; Terzi et al., 2007). On frontotemporal dementia (FTD) however, there are controversial results, no changes or increased levels have been reported (Olsson et al., 2005). The highest levels of tau in CSF positively correlate with the rate of degeneration, their being higher in CJD, moderate in AD and normal in patients with diseases with limited degeneration (Hesse et al., 2001). In CSF from HAM/TSP, a chronic disease, we found that total tau was significantly diminished compared to that of controls.

The significant increases in both $\mathrm{pT}^{181}$ level and tau-pT $\mathrm{T}^{181} /$ total tau ratio in CSF from HAM/TSP patients suggest the presence of a hyperphosphorylated isoform of tau. Hyperphosphorylation of $\mathrm{T}^{181}$ has been detected in the CSF of patients with $\mathrm{AD}$, with CJD both in VCJD and SCJD, with relapsing-remitting-MS, with $\mathrm{SD}$, and with cerebrovascular disease (Olsson et al., 2005; Goodall et al., 2006; Burguer et al., 2006; Skinningsrud et al., 2008; Otto et al., 2008). The increase in the level of $\mathrm{pT}^{181}$ is not a marker of simple neuronal loss (Hesse et al., 2001; Otto et al., 2008). Interestingly, in HAM/TSP, a large proportion of total tau is phosphorylated at $\mathrm{T}^{181}$, compared to all of these other pathologies, deduced from the higher values of the ratio $\mathrm{pT}^{181} /$ total tau. Compared to MS, CSF levels of total tau in HAM/TSP were not elevated, while a greater increase in $\mathrm{pT}^{181}$ was observed (BartosikPsujek and Stelmasiak, 2006). Nevertheless, the ratio $\mathrm{pT}^{181} /$ total tau was always higher in CSF from HAM/TSP than that of the other groups. It is not possible to conclude that a unique hyperphosphorylation at $\mathrm{T}^{181}$ could be exclusive to HAM/TSP, because among the various neurological diseases where this increase is also observed, only studies in CJD and AD have been done in CSF using specific antibodies against other phosphoresidues. These findings showed phosphorylation increases in residues $\mathrm{T}^{181}$, 

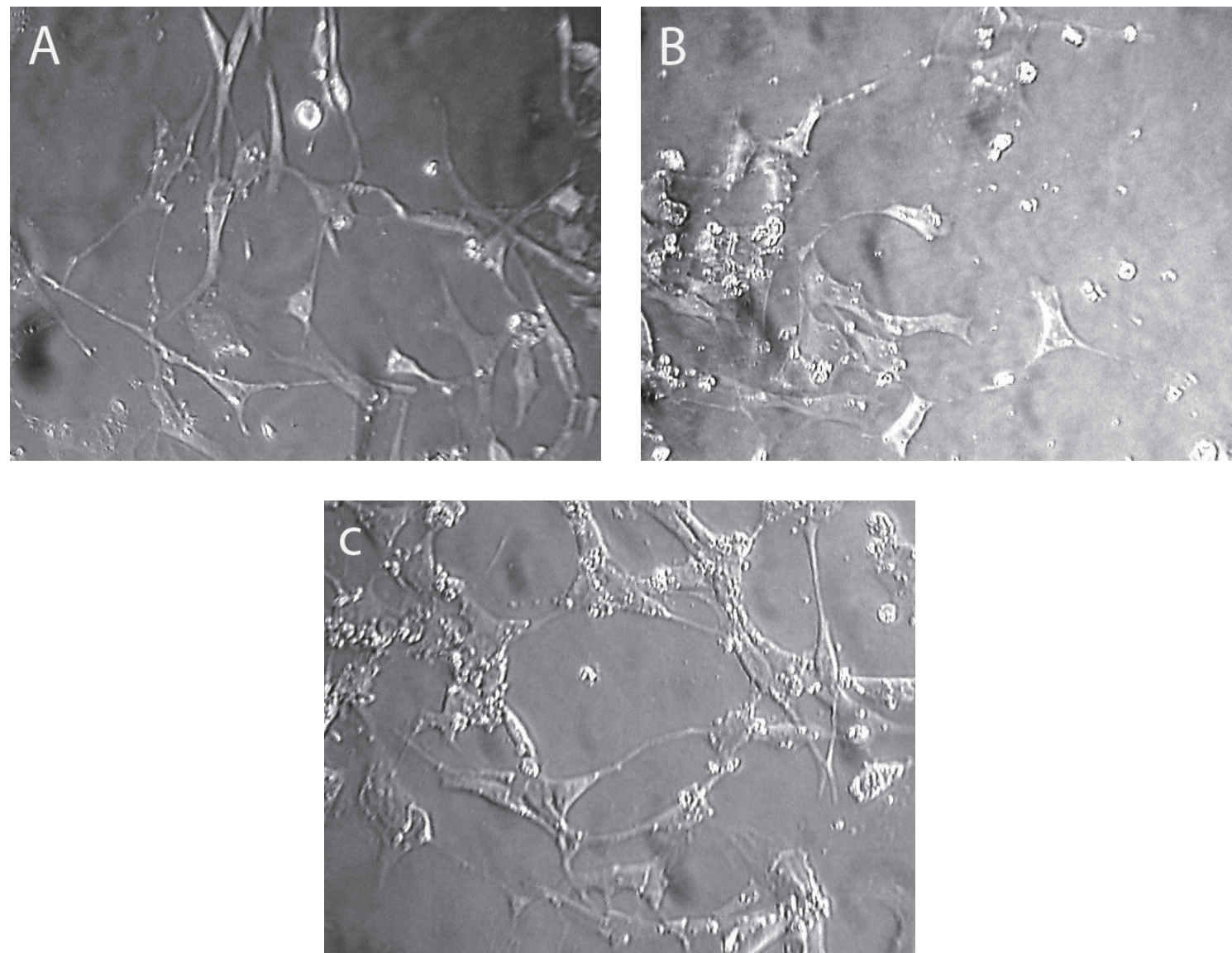

Figure 4: Neurite retraction induced by the addition of MT-2 supernatants. Differentiated SHSY5Y cells were treated with $600 \mu \mathrm{l}$ of MT-2 and K562 supernatants. After $60 \mathrm{~min}$, cells treated with MT-2 supernatants showed a reduction in the neurite length. A) Initial condition, differentiated cells; after 60 min of stimulus with MT-2 supernatant (B) and with K562 supernatant (C).

$\mathrm{S}^{199}, \mathrm{~S}^{202}$ and $\mathrm{S}^{404}$ in CJD, and in $\mathrm{T}^{181}, \mathrm{~S}^{199}$, $\mathrm{T}^{231}, \mathrm{~S}^{235}$ in $\mathrm{AD}$ (Van Everbroeck et al., 2002; Otto et al., 2008). Probably this residue could be more exposed to kinase actions due to its location in the aminoterminal projection domain (Shahani \& Brandt, 2002).

Abnormal phosphorylated tau has been related to axonal microtubule dysfunction causing neuron degeneration that could severely affect fast axonal transport and causing neuron degeneration (Shahani \& Brandt, 2002; Avila et al., 2004). Threonine 181 is not localized in the characteristic microtubule interaction site, but is within the projection domain. The precise dysfunctional implications of this phosphorylation are not clear (Shahani \& Brandt, 2002). Some in vitro studies indicate that the projection domain is involved in microtubule binding by reducing the dissociation constant and increasing the rate of interaction with tubulin, with no change in the stoichiometry (Gustke et al., 1994; Shahani \& Brandt, 2002). As well, this domain can interact with other cytoskeleton elements and fyn protein and $\operatorname{PLC} \gamma$, and is required for microtubule nucleation (Buée et al., 2000; Shahani \& Brandt, 2002).

The increase in tau-pT $\mathrm{T}^{181}$ could be due to an over-expression or activation of kinases, such as GSK-3 $\beta$ and Cdk5, that can act alone or be co-stimulated by PKA and CAMKII (Sengupta et al., 2006a,b; Li et al., 2006; Wang et al., 2007). A functional association of Cdk5-GSK-3 $\beta$-PP $2 \mathrm{~A}$ has been suggested, with a key mediator role of 
GSK-3 $\beta$ in tau hyperphosphorylation, where Cdk5 is a modulator of the phosphorylation acting via the inhibitory regulation of GSK-3 (Plattner et al., 2006). The regulation of tau phosphorylation by protein kinases also includes other residues, such as $\mathrm{S}^{199}, \mathrm{~T}^{205}, \mathrm{~T}^{231}, \mathrm{~S}^{262}, \mathrm{~S}^{356}, \mathrm{~S}^{404}$ and $\mathrm{S}^{422}$. However, in CSF of HAM/TSP, the tau isoform of $52 \mathrm{kDa}$ was similarly phosphorylated, as in controls in these residues (Table II) (Van Everbroeck et al., 2002; Hampel et al., 2005; Buerger et al., 2006; Sengupta et al., 2006a,b). A dysregulation of kinases/phosphatases could also affect the functioning of motor proteins and MAPs associated with transport and growth cone, respectively, because normal cellular function relies on the phosphorylation state.

The neurite retraction and increase in tau
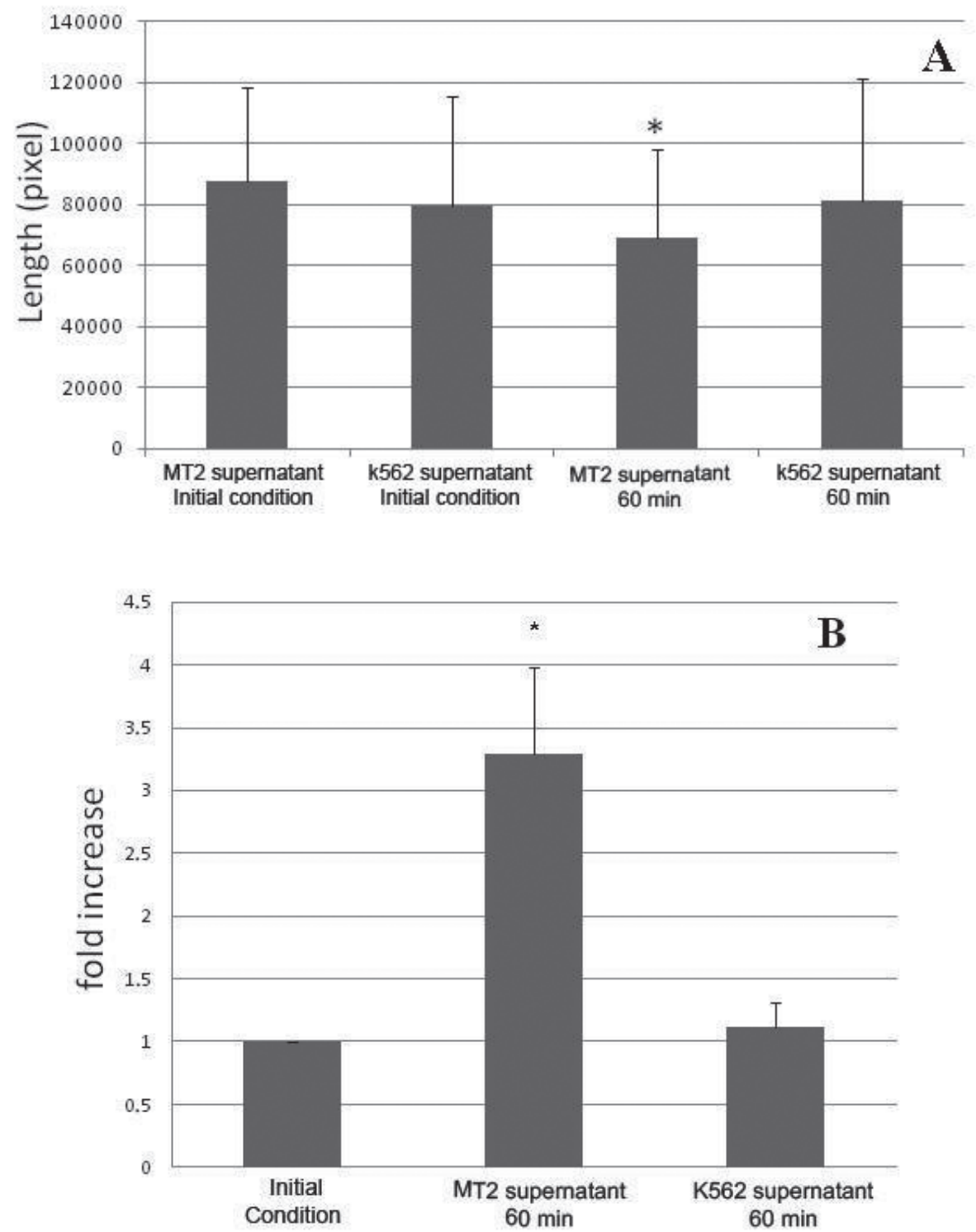

Figure 5: Effect of supernatant of MT-2 cells on differentiated SH-SY5Y cells. A) Neurite length expressed in pixels was measured using the NIH ImageJ-1.38d program plug-in neuronJ; B) Cell lysates showed an increased phosphorylation of tau at $\mathrm{T}^{181}$ followed by Western Blotting. Supernatant of K562 cells was used as control. Bars represent the mean \pm SD of triplicate cultures. 
phosphorylation in the human cell culture model treated with a supernatant of MT-2 that secretes Tax (Alefantis et al., 2005) agree with data observed in HAM/TSP patients that included axon degeneration and increase in tau phosphorylation at $\mathrm{T}^{181}$ deduced from cytological and CSF analyses, respectively. We chose the human neuroblastoma SH-SY5Y cell line because it is phenotipically similar to CNS pure neurons, producing long axon-like extensions (Sayas et al., 2002). We found a similar expression pattern of tau as that found in CSF. A single publication reports the extracellular effect of Tax protein on a differentiated neuronal cell line NT2-N, inducing TNF- $\alpha$ production. No studies on alteration of neurites have bee done (Cowan et al., 1997). Changes in the neuronal cytoskeleton occur during neurite retraction in response to extracellular signals, including rearrangements of microtubules, actin filaments and neurofilaments. In all cases, the activation of several kinases is involved (Sayas et al., 2002). There is work in progress to provide an association between the higher tau phosphorylation at $\mathrm{T}^{181}$ and kinase/phosphatase activities in the neuronal culture when it is submitted to the action of the secreted proteins from chronically HTLV-I infected MT-2 cells.

The abnormal hyperphosphorylation of tau might produce conformational changes that could make this protein either a better substrate for kinases or a worse substrate for phosphatases (Iqbal et al., 2005) and cause dettachment of tau from microtubules, leading to microtubule breakdown, disruption of axonal transport and axonal degeneration (Bartosik-Psujek \& Stelmasiak, 2006). Although we found hyperphosphorylation in $\mathrm{T}^{181}$ and phosphorylation in neurofibrillar tangles, these structures have not been detected in anatomo-pathological analysis (Cartier et al., 2007).

The findings of neurite retraction in the in vitro cell culture by the action of secreted products from MT-2 cells support further studies on possible external signals acting through intracellular signal transductions by interaction with cellsurface molecules, increasing the activity of some kinases or inhibiting Ser/Thrphosphatases.

\section{ACKNOWLEDGMENTS}

We acknowledge to Dr Christopher I. Pogson for his critical reading of the manuscript. This work was supported by Fondecyt grant 105-0784.

\section{REFERENCES}

ALEFANTIS T, MOSTOLLER K, JAIN P, HARHAJ E, GRANT C, WIGDAHL B (2005). Secretion of the human $\mathrm{T}$ cell leukemia virus type I transactivator protein tax. J Biol Chem 280: 17353-17362

ALONSO A DEL C, LI B, GRUNDKE-IQBAL I, IQBAL K (2006) Polymerization of hyperphosphorylated tau into filaments eliminates its inhibitory activity. Proc Natl Acad Sci U S A 103: 8864-8869

AVILA J, LUCAS JJ, PÉREZ M, HERNÁNDEZ F (2004) Role of tau protein in both physiological and pathological conditions. Physiol Rev 84: 361-384

BARTOSIK-PSUJEK H, STELMASIAK Z (2006) The CSF levels of total and phosphotau in patients with relapsing-remitting multiple sclerosis. J Neural Transm 113: $339-345$

BLENNOW $\mathrm{K}$, ZETTERBERG H, MINTHON L, LANNFELT L, STRID S, ANNAS P, BASUN H, ANDREASEN N (2007) Longitudinal stability of CSF biomarkers in Alzheimer's disease. Neurosci Lett 419: $18-22$

BORRONI B, GARDONI F, PARNETTI L, MAGNO L, MALINVERNO M, SAGGESE E, CALABRESI P, SPILLANTINI MG, PADOVANI A, DI LUCA M (2007). Pattern of Tau forms in CSF is altered in progressive supranuclear palsy. Neurobiol Aging. Aug 18. [Epub ahead of print]

BRETTSCHNEIDER J, PETZOLD A, JUNKER A, TUMANI H (2006a) Axonal damage markers in the cerebrospinal fluid of patients with clinically isolated syndrome improve predicting conversion to definite multiple sclerosis. Mult Scler 12: 143-148

BRETTSCHNEIDER J, PETZOLD A, SÜSSMUTH SD, LUDOLPH AC, TUNAMI H (2006b) Axonal damage markers in cerebrospinal fluid are increased in ALS. Neurology 66: 852-856

BUÉE L, BUSSIERE T, BUÉE-SCHERRER V DELACOURTE A, HOF PR (2000) Tau protein isoforms, phosphorylation and role in neurodegenerative disorders. Brain Res Brain Res Rev 33: $95-130$

BUERGER K, EWERS M, PIRTTILÄ T, ZINKOWSKI R, ALAFUZOFF I, TEIPEL SJ, DEBERNARDIS J, KERKMAN D, MCCULLOCH C, SOININEN H, HAMPEL H (2006) CSF phosphorylated tau protein correlates with neocortical neurofibrillary pathology in Alzheimer's disease. Brain 129: 3035-3041

CARTIER L, RAMÍREZ E (2005) Presence of HTLV-I Tax protein in cerebrospinal fluid from HAM/TSP patients. Arch Virol 150: 743-753

CARTIER L, VERGARA C, VALENZUELA MA (2007) Immunohistochemistry of degenerative changes in the central nervous system in spastic paraparesis associated 
to human T lymphotropic virus type I (HTLV-I). Rev Med Chil 135: 1139-1146

CARTIER LM, CEA J, VERGARA C, ARAYA F, BORN P (1997) Clinical and neuropathological study of six patients with spastic paraparesis associated with HTLV-I: an axomyelinic degeneration of the central nervous system. J Neuropathol Exp Neurol 56: 403-413

COWAN EP, ALEXANDER RK, DANIEL S, KASHANCHI F, BRADY JN (1997) Induction of tumor necrosis factor alpha in human neuronal cells by extracellular human T-cell lymphotropic virus type 1 Tax. J Virol 71: 6982-6989

DELUCA GC, EBERS G, ESIRI MM (2004) The extent of axonal loss in the long tracts in hereditary spastic paraplegia. Neuropathol Appl Neurobiol 30: 576-584

FERREIRINHA F, QUATTRINI A, PIROZZI M, VALSECCHI $\mathrm{V}$, DINA $\mathrm{G}$, BROCCOLI V, AURICCHIO A, PIEMONTE F, TOZZI G, GAETA L, CASARI G, BALLABIO A, RUGARLI EI (2004) Axonal degeneration in paraplegin-deficient mice is associated with abnormal mitochondria and impairment of axonal transport. J Clin Invest 113: 231-242

FU DX, KUO YL, LIU BY, JEANG KT, GIAM CZ (2003) Human T-lymphotropic virus type I tax activates Ikappa B kinase by inhibiting I-kappa B kinaseassociated serine/threonine protein phosphatase $2 \mathrm{~A}$. J Biol Chem 278: 1487-1493

GALENO H, RAMÍREZ E, MORA J, OJEDA M, CARTIER L (1994) Anti HTLV-I antibody titers in seropositive infected individuals. Rev Med Chil 122: 1004-1007

GOODALL CA, HEAD MW, EVERINGTON D, IRONSIDE JW, KNIGHT RS, GREEN AJ (2006) Raised CSF phospho-tau concentrations in variant Creutzfeldt-Jakob disease: diagnostic and pathological implications. J Neurol Neurosurg Psychiatry 77: 89-91

GRANT C, BARMAK K, ALEFANTIS T, YAO J, JACOBSON S, WIGDAHL B (2002) Human T cell leukemia virus type I and neurologic disease: events in bone marrow, peripheral blood, and central nervous system during normal immune surveillance and neuroinflammation. J Cell Physiol 190: 133-159

GUSTKE N, TRINCZEK B, BIERNAT J, MANDELKOW EM, MANDELKOW E (1994) Domains of tau protein and interactions with microtubules. Biochemistry 33: 9511-9522

HAMPEL H, BURGER K, PRUESSNER JC, ZINKOWSKI R, DEBERNARDIS J, KERKMAN D, LEINSINGER G, EVANS AC, DAVIES P, MÖLLER HJ, TEIPEL SJ (2005) Correlation of cerebrospinal fluid levels of tau protein phosphorylated at threonine 231 with rates of hippocampal atrophy in Alzheimer disease. Arch Neurol 62: 770-773

HESSE C, ROSENGREN L, ANDREASEN N, DAVIDSSON P, VANDERSTICHELE H, VANMECHELEN E, BLENNOW K (2001). Transient increase in total tau but not phospho-tau in human cerebrospinal fluid after acute stroke. Neurosci Lett 297: $187-190$

IQBAL K, ALONSO A DEL C, CHEN S, CHOHAN MO, EL-AKKAD E, GONG CX, KHATOON S, LI B, LIU F, RAHMAN A, TANIMUKAI H, GRUNDKE-IQBAL I (2005) Tau pathology in Alzheimer disease and other tauopathies. Biochim Biophys Acta 1739: 198-210

JÄMSÄ, HASSLUND K, COWBURN RF, BÄCKSTRÖM A, VASÄNGE M (2004). The retinoic acid and brainderived neurotrophic factor differentiated SH-SY5Y cell line as a model for Alzheimer's disease-like tau phosphorylation. Biochem Biophys Res Commun 319: 993-1000
JAIN P, MOSTOLLER K, FLAIG KE, AHUJA J, LEPOUTRE $\mathrm{V}$, ALEFANTIS T, KHAN ZK, WIGDAHL B (2007) Identification of human T cell leukemia virus type 1 tax amino acid signals and cellular factors involved in secretion of the viral oncoprotein. J Biol Chem 282: 34581-34593

JOHNSON GV, STOOTHOFF WH (2004) Tau phosphorylation in neuronal cell function and dysfunction. J Cell Sci 117: 5721-5729

KREITZER G, LIAO G, GUNDERSEN GG (1999) Detyrosination of tubulin regulates the interaction of intermediate filaments with microtubules in vivo via a kinesin-dependent mechanism. Mol Biol Cell 10: 11051118

LI T, HAWKES C, QURESHI HY, KAR S, PAUDEL HK (2006) Cyclin-dependent protein kinase 5 primes microtubule-associated protein tau site-specifically for glycogen synthase kinase 3beta. F Biochemistry 45: 3134-3145

MACCIONI RB, LAVADOS M, GUILLON, MUJICA C, BOSCH R, FARÍAS G, FUENTES P (2006) Anomalously phosphorylated tau and Abeta fragments in the CSF correlates with cognitive impairment in MCI subjects. Neurobiol Aging 27: 237-244

MONDRAGÓN-RODRÍGUEZ S, BASURTO-ISLAS G, SANTA-MARÍA I, MENA R, BINDER LI, ÁVILA J, SMITH MA, PERRY G, GARCÍA-SIERRA F (2008) Cleavage and conformational changes of tau protein follow phosphorylation during Alzheimer's disease. Int J Exp Pathol 89: 81-90

NOGALES E (2000) Structural insights into microtubule function. Annu Rev Biochem 69: 277-302

OLSSON A, VANDERSTICHELE H, ANDREASEN N, DE MEYER G, WALLIN A, HOLMBERG B, ROSENGREN L, VANMECHELEN E, BLENNOW K (2005) Simultaneous measurement of beta-amyloid(142), total tau, and phosphorylated tau (Thr181) in cerebrospinal fluid by the xMAP technology. Clin Chem 51: 336-345

OSAME M (2002) Pathological mechanisms of human Tcell lymphotropic virus type I-associated myelopathy (HAM/TSP). J Neurovirol 8: 359-364

OTTO M, LEWCZUK P, WILTFANG J (2008) Neurochemical approaches of cerebrospinal fluid diagnostics in neurodegenerative diseases. Methods 44: 289-298

PLATTNER F, ANGELO M, GIESE KP (2006) The roles of cyclin-dependent kinase 5 and glycogen synthase kinase 3 in tau hyperphosphorylation. J Biol Chem 281: 25457-25465

RAMÍREZ E, FERNÁNDEZ J, CARTIER L, VILLOTA C, RÍOS M (2003) Defective human T-cell lymphotropic virus type I (HTLV-I) provirus in seronegative tropical spastic paraparesis/HTLV-I-associated myelopathy (TSP/HAM) patients. Virus Res 91: 231-239

RAMÍREZ E, CARTIER L, FLORES R (2004) In vitro cytoskeleton changes of mouse neurons induced by purified HTLV-1, and PBMC from HAM/TSP patients and HTLV-1 carriers. Arch Virol 149: 2307-2317

SAYAS CL, AVILA J, WANDOSELL F (2002) Regulation of neuronal cytoskeleton by lysophosphatidic acid: role of GSK-3. Biochim Biophys Acta 1582: 144-153

SEMRA YK, SEIDI OA, SHARIEF MK (2002) Heightened intrathecal release of axonal cytoskeletal proteins in multiple sclerosis is associated with progressive disease and clinical disability. J Neuroimmunol 122: 132-139

SENGUPTA A, GRUNDKE-IQBAL I, IQBAL K (2006a) Regulation of phosphorylation of tau by protein kinases in rat brain. Neurochem Res 31: 1473-1480 
SENGUPTA A, NOVAK M, GRUNDKE-IQBAL I, IQBAL K (2006b) Regulation of phosphorylation of tau by cyclin-dependent kinase 5 and glycogen synthase kinase-3 at substrate level. FEBS Lett 580: 5925-5933

SERGEANT N, DELACOURTE A, BUÉE L (2005) Tau protein as a differential biomarker of tauopathies. Biochim Biophys Acta 1739: 179-197

SHAHANI N, BRANDT R (2002) Functions and malfunctions of the tau proteins. Cell Mol Life Sci 59: 1668-1680

SJÖGREN M, DAVIDSSON P, TULLBERG M, MINTHON L, WALLIN A, WIKKELSO C, GRANÉRUS AK, VANDERSTICHELE H, VANMECHELEN E, BLENNOW K (2001) Both total and phosphorylated tau are increased in Alzheimer's disease. J Neurol Neurosurg Psychiatry 70: 624-630

SKINNINGSRUD A, STENSET V, GUNDERSEN AS, FLADBY T (2008) Cerebrospinal fluid markers in Creutzfeldt-Jakob disease. Cerebrospinal Fluid Res. 27; 5: 14 (Doi: 10.1186/1743-8454-5-14)

SZYMOCHA R, AKAOKA H, DUTUIT M, MALCUS C, DIDIER-BAZES M, BELIN MF, GIRAUDON P (2000). Human T-cell lymphotropic virus type 1infected T lymphocytes impair catabolism and uptake of glutamate by astrocytes via Tax-1 and tumor necrosis factor alpha. J Virol 74: 6433-6441

TERZI M, BIRINCI A, CETINKAYA E, ONAR MK (2007) Cerebrospinal fluid total tau protein levels in patients with multiple sclerosis. Acta Neurol Scand 115: $325-330$
TEUNISSEN CE, DIJKSTRA C, POLMAN C (2005): Biological markers in CSF and blood for axonal degeneration in multiple sclerosis. Lancet Neurol 4: $32-41$

TRINCZEK B, EBNETH A, MANDELKOW EM MANDELKOW E (1999) Tau regulates the attachment/ detachment but not the speed of motors in microtubuledependent transport of single vesicles and organelles. J Cell Sci 112: 2355-2367

UMEHARA F, ABE M, KOREEDA Y, IZUMO S, OSAME M: (2000) Axonal damage revealed by accumulation of beta-amyloid precursor protein in HTLV-I-associated myelopathy. J Neurol Sci 176: 95-101

VAN EVERBROECK B, GREEN AJ, VANMECHELEN E, VANDERSTICHELE H, PALS P, SÁNCHEZ-VALLE R, CORRALES NC, MARTIN JJ, CRAS P (2002) Phosphorylated tau in cerebrospinal fluid as a marker for Creutzfeldt-Jakob disease. J Neurol Neurosurg Psychiatry 73: 79-81

WANG JZ, GRUNDKE-IQBAL I, IQBAL K (2007) Kinases and phosphatases and tau sites involved in Alzheimer neurofibrillary degeneration. Eur J Neurosci 25: 59-68

WU K, BOTTAZZI ME, DE LA FUENTE C, DENG L, GITLIN SD, MADDUKURI A, DADGAR S, LI H, VERTES A, PUMFERY A, KASHANCHI F (2004) Protein profile of tax-associated complexes. J Biol Chem 279: 495-508 